\title{
Implementation of Social Media Application as Recruitment Platform: Impact on Job Seekers and Intention to Apply
}

\author{
Hamzah Muhammad Mardi Putra \\ Pelita Bangsa University \\ hamzah@pelitabangsa.ac.id
}

\begin{abstract}
The rapid development of technology on businesses activity nowadays increase the growth of electronic commerce and mobile commerce user globally. Analysts predict that total work force will keep on raising in worldwide and companies will escalate the investment on development of electronic commerce and mobile commerce activity. The aim of this study isto explore the behavior and characteristic of work force on mobile phone through social media platform and mobile application. To implement this study, the researcher need the data about characteristic and behavior of work force who use social media platform and mobile application in ten big cities in Indonesia. The data of characteristic of work force consists of age, sex, education, occupation, the number of family members, income per month, and marital status.
\end{abstract}

Keywords: Recruitment, Social Media, Job Seeker, Behavior

\section{Introduction}

Recruitment is the process of attaining a pool of candidates who will be the position following the Selection part. Recruitment with Selection process, is one of the most classical area of organizational psychology strategy and research. The importance of gaining the most skilled and good workers has led to changes in the process to be a good organization (Saks, 2005).

Recruitment is an activity of attracting, filtering and selecting a pool of candidates (employees most suitable in skills, experience and competencies). Conventional recruitment processes spend more time and money and the best organizations hire the best employees at the lowest cost. This is a necessity in competing for a competitive advantage in the industrial world. Over time, the recruitment process has changed from conventional methods to methods by applying technology such as through website-based recruitment, job street, and social media.

The Linkedin Social Media App is a professional Social Media platform with 443 million users in around 200 countries. By using LinkedIn's professional social media as a tool for recruitment, job seekers and companies who need labor will be facilitated. The method used in this study is to determine the suitability of job seekers with the criteria required by the company in the context of the workforce recruitment process. Data collection will be used for job seekers in the Jababeka Industrial area and will be adjusted to companies in the Jababeka Industrial area.

The expected output from the implementation of the Linkedin social media application as a recruitment tool is expected to save time and recruitment costs that are usually incurred by companies in the search for labor. The application of this research is expected to be a solution for job seekers and companies in the industrial area in the labor recruitment process, so that efficiency can occur in the recruitment process. The results of this research will be published in 
the National Journal and National Seminar Proceedings.

Social Media as a recruitment tool has many advantages such as providing access to prospective employees with different competencies and skills (Doherty, 2010). The Implementation of Media Social Application as a recruitment tool also provides a more attractive technology to use. (Galanaki, 2002). The recruitment process has not proven its accuracy and fairness and the selection criteria are not necessarily the same between companies. The information displayed is very important to choose and is often inaccurate with industry needs and workforce user satisfaction (Sylva \& Mol, 2009).

The Linkedin Social Media application is a professional social media platform with 443 million users in around 200 countries in the world. Linkedin's mission is to support companies in need of manpower and recruiting (acquiring talent and recruiting talent pool (talent pool), marketing and sales (increasing the social sales efforts of social media users). Linkedin also provides recruiting companies with advice for recruiting organizations. The key to the Linkedin platform as a recruitment tool is to build relationships with candidates long before they apply to employers.

\section{Literature Review}

While into to the globalization era, the researcher found some previous academic research that related to this topic which focus on Strategic Management in an Human Resource context, and this framework in this study was developed before by Bruettner (2014) for social media recruitment that includes the entire organizational environment and the workforce in it. This framework constructed will be broken down into sub-fit with the appropriate consisting of three except the discontinuous sub-fit, which together cover almost the entire fit of the organizational environment (Kristof-Brown, 2005). This sub-fit is The suitability of the people's organization environment, Group suitability of people andCompatibility of work with people

Employees are those who meet the needs of the organization with a culture that matches their personality. A macro-level assessment of person-organization suitability is indicated and according to the rules carried out by consulting firms such as HRD (Human Resource Development). Person group suitability assessment (medium level) was related to social interaction (communication style and group roles) in group work between co-workers. In most companies, the recruiter (HRD) evaluates this suitability through some specific interview question. Finally, at the micro level, recruiters evaluate person-job suitability based on the candidate's skills, knowledge and abilities as well as the specific job demands. This is usually done by an in-person examination of the candidate's CV, testimonials and reference letter along with a job description. An investigative overview of this research and further subfit can be found in publication by Buettner (2014).

\subsection{Human Resurce Department}


The Human Resource department (HRD) is especially active in recruitment and selection activities as one of the eight core Human Resource function (Buettner, 2014). By Focus on this concept, classic Human Resource consulting organization can propose a set of job specific candidates suitable for hiring organization. By searching for candidates was very time consuming and many cost. This approach provides Human Resource consultant with the opportunity to receive recommendations from suitable candidates based on social media analysis for personality related information can be found. In the first step, the hiring organization asks the Human Resource consultant organization to find a specific employee and then they submits the organizational culture profile to fit the HR consulting organization (step two). After that step, Human Resource consulting firms are looking for candidate or accepting applications from interested people (step three). Step four consists of request the Human Resource consulting organization for a personality assessment using a personality prediction web service sending the candidate's personality trait to the Human Resource consulting organization which select the most suitable applicant and submitting this applicants including the culture personality fit score to organizational recruitment.

\subsection{Media Social Implementation}

Previous research on conventional recruitment appears to lack practice and little knowledge of job seeker criteria and reactions to internet recruitment processes although there are some that are relevant to Human Resource Management practitioners and among job seekers (Sylva \& Mol, 2009). Social media platforms, such as facebook, twitter and Linkedin, are change human interactions and the how people access personal information in an evolving online environment. Media Social we called Linkedin for example, is an example of unsustainable innovation - new products that shape new patterns of behavior (Assael, 1984) and influence the way human resource (HR) professionals recruit, screen, recruit, and lay off employees (Brandenburg, 2008; Brown and Vaughn) 2011; Clark and Roberts, 2010; Davison et al., 2011). As has been done by Davidson et al. (2011), "Technology is currently set to revolutionize the way human resource management (HRM) is done".

Some research by famous practitioners in Global era suggest that the increasing use and many interest in Social Media platforms, such as Facebook, Twitter and Linkedin, there is an ambiguous understanding of the term "social media". Kaplan and Haenlein (2010) describe Media Social as a group of Internet base application that operating on the basis of Web 2.0 and user generated content. Driven by the technical, increased hardware capacity and access to the Internet, economic and social (eg, Generation Y engagement with technology) influences of Web 2.0 (Kaplan and Haenlein, 2010), Social Media adoption has been exponential information. Recent data by practitioners show that the majority of male respondents (63\%) and female respondents (75\%) Internet users use most the Social Media platform (Pew Internet, 2012). Although Social Media application are originally developed for social reasons, businesses now using these apps to interact with customer and potential employee in platform online space. 


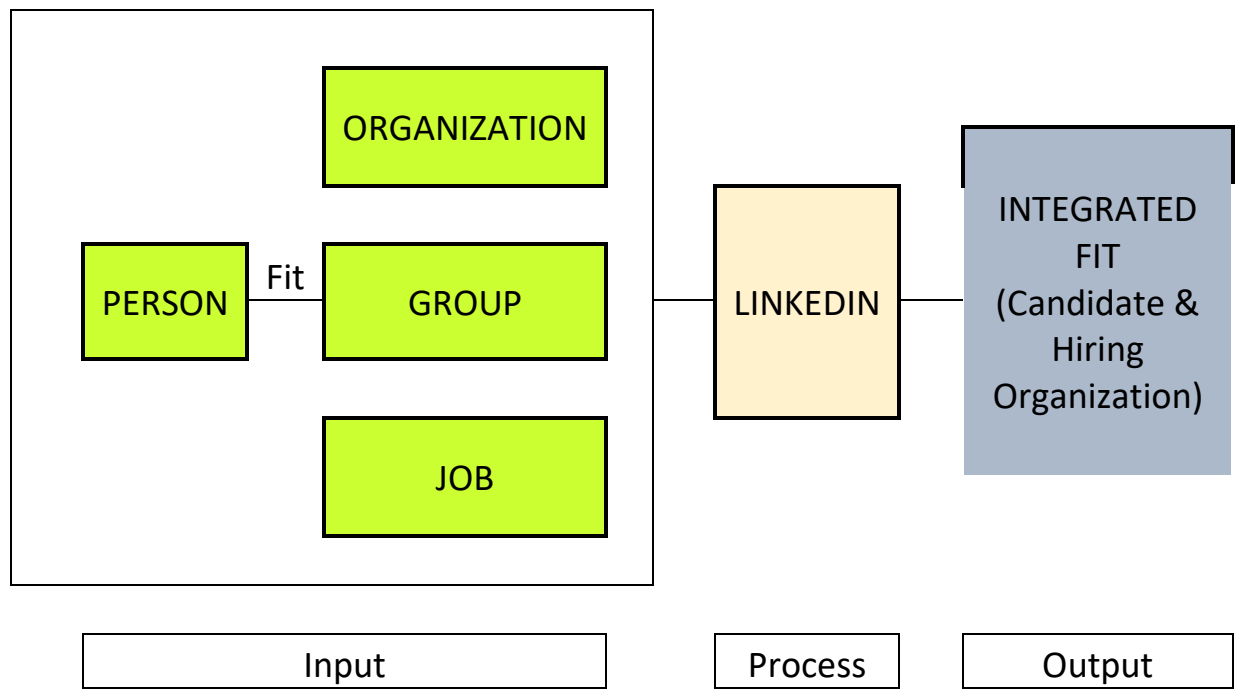

\section{Methode}

The research method used in this study describes a systems approach or model of input, process, output. The input of this research includes the suitability of person to organization, person to group, and person to work. On the other hand, the process is social media, Linkedin, and the result is a match between the candidate and the integrated recruiting organization. The analysis tools used are Factor Analysis and Path Analysis, namely the analysis of research variables by connecting between variables to determine suitability.

Specifically, respondents in this study included needs, values, goals, personality, knowledge, competence, skills, abilities, and individual demographics needed by the industry in the Jababeka industrial area. In particular, people - organization suitability consists of the conformity of people to organizational climate and organizational culture; the person - group fit consists of the fit of person with group relationships with each other, peers, supervisors and subordinates; the person - job fit consists of the type of work, work load demands, work environment, career path, compensation, quality of 
life, health and well-being.

The process is Linkedin which is a professional social networking and career development website which is used as a popular tool in recruitment, selection and recruiting. Finally, the output is an integrated match between the candidate and the recruiting organization that will result in high performance.

The research consists of three parts. The first part of the questionnaire consists of filtering questions to select respondents who fit the inclusion criteria, namely respondents who use the Linkedin social media application to find work. The second part of the questionnaire is related to questions about research variables which consist of six tables. The second part is collected through a Likert scale consisting of 6 levels, namely STS (Strongly Disagree), TS (Disagree), ATS (Somewhat Agree), US (Somewhat Agree), S (Agree), and SS (Strongly Agree). The third part of the questionnaire consists of questions in the form of respondent demographic data. The data collection process begins with a word test on the questionnaire, pre-test the questionnaire, then begins the distribution of the questionnaire. The word test on the questionnaire was conducted to test whether the sentences in the questionnaire were neatly arranged according to EYD (Enhanced Spelling). A pretest questionnaire was conducted to test whether the questionnaire was ready to be distributed. The questionnaire test was conducted by testing the validity and reliability of the research questionnaire.

\section{Sampling method}

Respondents in this study were selected from industrial sectors in the Jababeka Industrial Area which are grouped into manufacturing, trade, education and health clusters, especially in the Jababeka Industrial Area. Determination of five clusters to determine the difference between respondents in one company area and responses in various industrial fields. The choice of company was determined at the time of the research that there were not many outside options because the Covid-19 Pandemic was happening so it was difficult to find work outside the area.

\section{Result and Discussion}


The Result of this research show that Media Social in nowadays works life is important. Based on the research, social media become valuable platform and source of information. The major positive impact by profiling personal advertisement. In this paper, we tell an approach for utilizing social media as Human Resource consulting platform. We proposed this platform for Human Resource recruitment application, selection based on automated assessment of personality organization environment fit. The platform show us that personalization trait can be automatically derived from social media usage. The personality culture fit can be automatically computed and optimized so that the higher job performance, job satisfaction, organizational commitment and lower employee turnover.

The legal and ethical problem can be analyses based on information directly. We can established a new business process so Human Resource consulting department can implement the human resource strategy effectively. In the other hand, many company can provide the platform to small and medium organization. So, the integration of third party overcome legal and ethical issues.

\section{References}

[1] Berger, L.A., \& Berger, D.R. (2004). The Talent Management Handbook: Creating Organizational Excellence by Identifying, Developing \& Promoting Your Best People. New York: McGraw-Hill.

[2] Broekhuizen, Thijs. (2006). Understanding Channel Purchase Intention: Measuring Online dan Offline Shopping Value Perceptions. Labyrinth Publication: Belanda.

[3] Cheng, Zhang \& Qin. (2015). Big Data Analytics wth Swarm Intelligence.

[4] Industrial Management \& Data Systems. Vol. 116 no. 4. 2016.

[5] Cooper, D.R. \& Schindler, P.S. (2014). Business Research Methods. (12 ${ }^{\text {th }}$ edition). McGraw-Hill: Boston

[6] Cresswell, John W. (2014). Research Design: Pendekatan Metode Kualitatif, Kuantitatif, dan Campuran. Yogyakarta: Pustaka Belajar.

[7] Darrag, Mohamed, \& Aziz. (2010). Investigating Recruitmen Practices and Problem of Multinational Companies (MNCs) Operating in Egypt. Education, Business and Society: Contemprary Middle Eastern Issues vol. 3 Iss 2. p.99-116

[8] Dessler, Gary. (2013). Human Resources Management (13th ed.). New Jersey: Pearson Education, Inc.

[9] El-Kot, Ghada \& Leat, Mike. (2008). A Survey of Recruitment and Selection Practices in Egypt. Education, Business, and Society: Contemporary Middle Eastern Issues vol. 1 Iss 3. p.200-212.

[10] Haubl, Gerarld dan Trifts, V. (2000). Consumer Decision Making Online Shopping Environment: The Effects of Interactive Decision Aids. Marketing Science. Vol. 19, no. 1. Pp 4-21.

[11] Heijden, Verhagen dan Creemers. (2003). Understanding online purchase intentions: contribution from technology and trust perspectives. European Journal of Information System. 12 Pp 41-48.

[12] Heneman, H.G. III, \& Judge T.A. (2004). Staffing Organizations (4th ed.). New York: McGrawHill.

[13] Kotler, P. dan Armstrong, G. (2004). Principles of Marketing. (10 ${ }^{\text {th }}$ edition). Upper Saddle River, Prentice Hall: New Jersey.

[14] Li, Na dan Zhang, Ping. (2002). Consumer Online Shopping Attitudes and Behavior: An Assessment of Research. Eigth Americas Conference on Information System.

[15] Lind, Marchal, \& Wathen. (2011). Statistical Techniques in Business \& Economics. (14 ${ }^{\text {th }}$ Ed)., McGraw-Hill.

[16] Meng, Xiaoming. (2009). Developing of E-commercce E-marketing. Proceedings of the 2009 International Symposium on Information Processing. Huangshan, August 21-23 2009. pp 225-228. 
[17] Nielsen. (2016). Global Connected Commerce Report January 2016.

[18] Noe, Hollenback, Gerhart, Wright (2008) Human Resource Management: Gaining a Competitive advantage. ( $9^{\text {th }}$ edition). McGraw-Hill: Boston.

[19] Smilansky, Jonathan (2007). Developing Exdecutive Talent: Best Practices from Global Leaders. Chichester: John Wiley \& Sons.

[20] SparkLabs Global Ventures. (2015). E-Commerce Trends in Asia February 2015. SparkLabs.

[21] Wu, Jen-Her dan Wang, Shu-Ching. (2003). An Emprical Study of Consumer Adpoting Mobile Commerce in Taiwan: Analyzed by Structural Equation Modeling. $7^{\text {th }}$ Pacific Asia Conference on Information System. Adelaide. 10-13 July 2003

[22] Yullyati, Ellyta. (2009). Analisis Proses Rekrutmen dan Seleksi pada Kinerja Pegawai. Bisnis \& Birokrasi, Jurnal Ilmu Administrasi dan Organisasi Sep-Des 2009. p.131-139. 